\title{
Pharmacogenomic considerations in opioid analgesia. [Corrigendum]
}

Vuilleumier PH, Stamer UM, Landau R. Pharmacogenomic considerations in opioid analgesia. Pharmacogenomics and Personalized Medicine. 2012;5:73-87.

The authors regret an error in their Figure 1, CYP metabolism involved in opioid clearance. The correct figure is shown below.

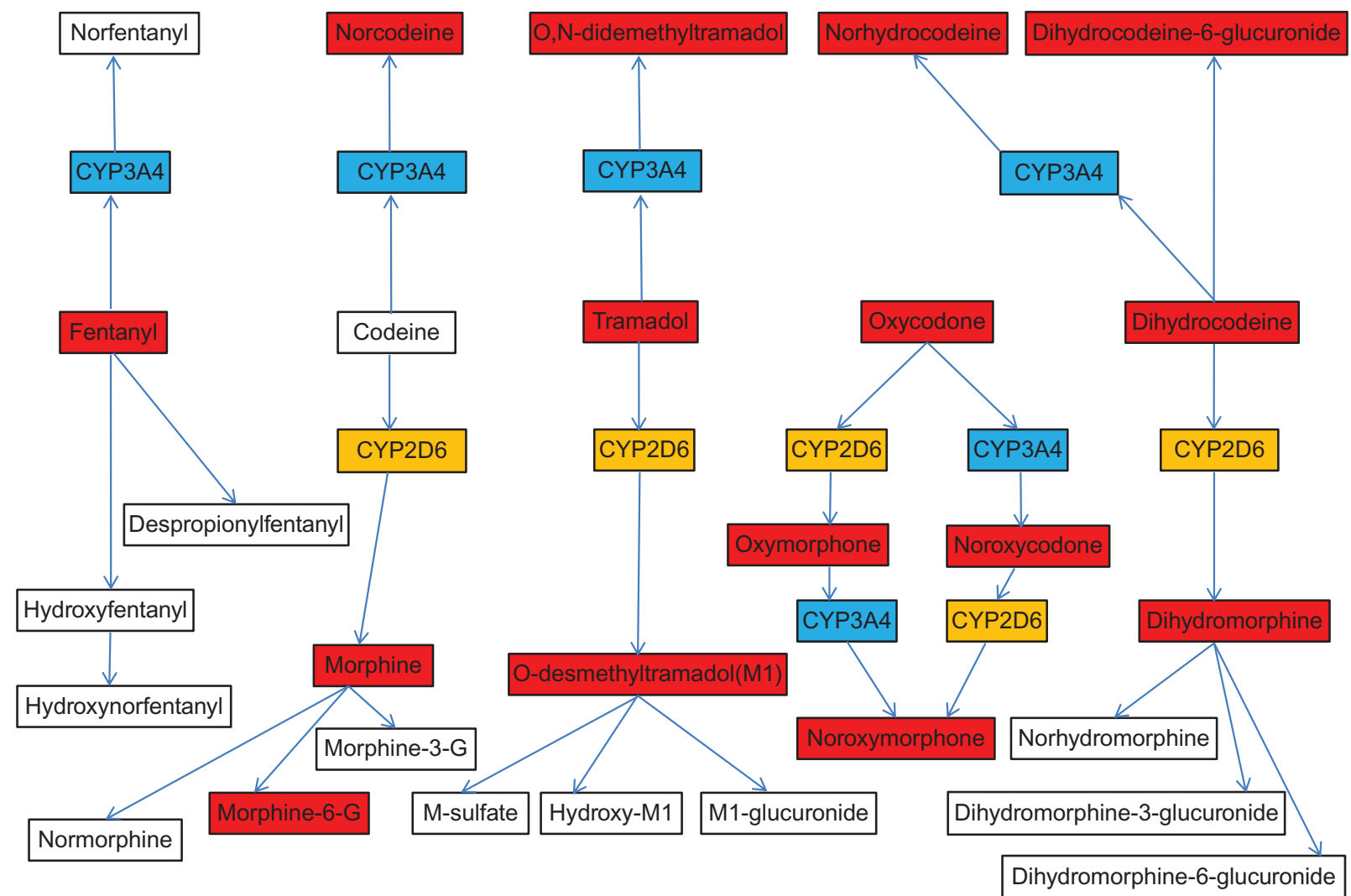

Figure I

\section{Publish your work in this journal}

Pharmacogenomics and Personalized Medicine is an international, peerreviewed, open access journal characterizing the influence of genotype on pharmacology leading to the development of personalized treatment programs and individualized drug selection for improved safety, efficacy and sustainability. This journal is indexed on the American Chemical
Society's Chemical Abstracts Service (CAS). The manuscript management system is completely online and includes a very quick and fair peer-review system, which is all easy to use. Visit http://www.dovepress. com/testimonials.php to read real quotes from published authors. 